\title{
Biodiversidata: An Open-Access Biodiversity Database for Uruguay
}

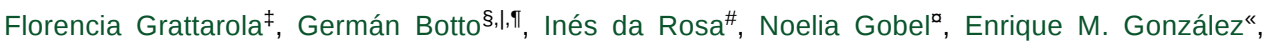
Javier González", Daniel Hernández”, Gabriel Laufer", Raúl Maneyro\#, Juan A. Martínez-Lanfranco

" ", Daniel E. Naya”, Ana L. Rodales", Lucía Ziegleri', Daniel Pincheira-Donoso?

‡ School of Life Sciences, University of Lincoln, Brayford Campus, Lincoln, United Kingdom

$\S$ Department of Micriobiology and Immunology, Montana State Universitiy, Bozeman, United States of America

| Departamento de Métodos Cuantitativos, Facultad de Medicina, Universidad de la República, Montevideo, Uruguay

I Programa para la Conservación de los Murciélagos de Uruguay, Museo Nacional de Historia Natural, Montevideo, Uruguay

\# Laboratorio de Sistemática e Historia Natural de Vertebrados, Facultad de Ciencias, Universidad de la República, Montevideo,

Uruguay

a Área Biodiversidad y Conservación, Museo Nacional de Historia Natural, Montevideo, Uruguay

« Museo Nacional de Historia Natural, Montevideo, Uruguay

» NGO JULANA (Jugando en la Naturaleza), Montevideo, Uruguay

^ Department of Wildlife, Fisheries and Aquaculture, Mississippi State University, Mississippi, United States of America

` Departamento de Ecología y Evolución, Facultad de Ciencias, Universidad de la República, Montevideo, Uruguay

Centro Universitario Regional del Este (CURE), Universidad de la República, Maldonado, Uruguay

$?$ MacroBiodiversity Lab, School of Science and Technology, Department of Biosciences, Trent University, Nottingham, United Kingdom

Corresponding author: Florencia Grattarola (fgrattarola@lincoln.ac.uk)

Academic editor: Ross Mounce

Received: 15 May 2019 | Accepted: 14 Jun 2019 | Published: 20 Jun 2019

Citation: Grattarola F, Botto G, da Rosa I, Gobel N, González E, González J, Hernández D, Laufer G, Maneyro R, Martínez-Lanfranco J, Naya D, Rodales A, Ziegler L, Pincheira-Donoso D (2019) Biodiversidata: An Open-Access Biodiversity Database for Uruguay. Biodiversity Data Journal 7: e36226. https://doi.org/10.3897/BDJ.7.e36226

\section{Abstract}

\section{Background}

The continental and marine territories of Uruguay are characterised by a rich convergence of multiple biogeographic ecoregions of the Neotropics, making this country a peculiar biodiversity spot. However, despite the biological significance of Uruguay for the South American subcontinent, the distribution of biodiversity patterns in this country remain poorly understood, given the severe gaps in available records of geographic species distributions. 
Currently, national biodiversity datasets are not openly available and, thus, a dominant proportion of the primary biodiversity data produced by researchers and institutions across Uruguay remains highly dispersed and difficult to access for the wider scientific and environmental community. In this paper, we aim to fill this gap by developing the first comprehensive, open-access database of biodiversity records for Uruguay (Biodiversidata), which is the result of a large-scale collaboration involving experts working across the entire range of taxonomic diversity found in the country.

\section{New information}

As part of the first phase of Biodiversidata, we here present a comprehensive database of tetrapod occurrence records native from Uruguay, with the latest taxonomic updates. The database provides primary biodiversity data on extant Amphibia, Reptilia, Aves and Mammalia species recorded within the country. The total number of records collated is 69,380, spanning 673 species and it is available at the Zenodo repository: https:// doi.org/10.5281/zenodo.2650169. This is the largest and most geographically and taxonomically comprehensive database of Uruguayan tetrapod species available to date and it represents the first open repository for the country.

\section{Keywords}

Uruguay, Biodiversity, Species Occurrence Records, Tetrapods, Amphibia, Reptilia, Aves, Mammalia

\section{Introduction}

Uruguay encompasses a peculiar area of South America located within the Pampa Province of the Neotropical Region (Morrone 2014). Both the continental and marine territories currently covered by Uruguay are known to represent rich areas of convergence of diverse environments as heterogeneous as the Amazon, the Pampa, Patagonia and Subantarctic subregions (Morrone 2006, Calliari et al. 2003). For example, Grela (2004) suggests the existence of a phytogeographic longitudinal division of the country's territory, with a western area characterised by the occurrence of Paranaense and Chaco species and an eastern area marked by different Paranaense species and relicts of flora from the Brazilian Cerrado (Grela and Brussa 2003). Additionally, Arballo and Cravino (1999) and Gonzalez and Martínez-Lanfranco (2010) describe the similarities between the bird and mammal assemblages of Uruguay and the species from adjacent subregions, indicating the spatial convergence of lineages from Brazilian and Andino-Patagonian origins. The reptiles and amphibians, on the other hand, are the result of lineage radiations that come from subregions as contrasting as Patagonia and the Amazon (Pincheira-Donoso 2010). Given these unique biodiversity features, the geographic region, encompassed by the territory of Uruguay, has been proposed to represent a differentiated unit of Pampa, 
defined by the unique composition of its flora and fauna (Chebataroff 1942, Dos Santos et al. 2016). Therefore, it is surprising that these biogeographic features, combined with the country's small territorial area $(176,220 \mathrm{~km} 2)$ and its relatively uniform elevational topography (513 m maximum altitude), remain one of the poorest-known across the Americas as a whole. These limitations apply fundamentally to any measure of biodiversity, such as the patterns of distribution of species-richness, endemism and threatened species (Canavero et al. 2010, Soutullo et al. 2013). Collectively, such lack of information hampers any attempts to assess, strategically study and manage the biodiversity and the natural resources of the country.

Currently, national biodiversity databases are unavailable and, thus, the dominant proportion of the primary biodiversity data produced in the country is highly dispersed and difficult to access for the wider scientific community and for policy-makers. Likewise, the Global Biodiversity Information Facility (GBIF) reveals that Uruguay ranks amongst the countries of America with the lowest levels of available data on their biodiversity (Fig. 1). In the GBIF platform (as of 7 June 2019), 73.5\% of the records belong to the Aves Class, all of which proceed from the eBird initiative. As shown in Fig. 1 , the overwhelming contribution of records provided by eBird to GBIF highlights the enormous role that data, provided by citizens, play in the development of global biodiversity datasets, while at the same time, points out the critical taxonomical biases encountered in GBIF for the region.

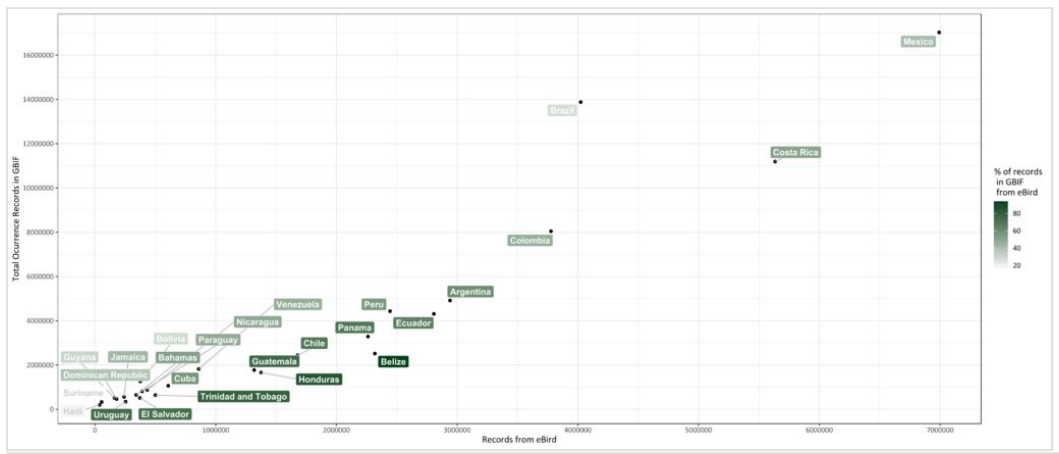

Figure 1. doi

Distribution of the number of occurrence records available in the Global Biodiversity Information Facility (GBIF) (as of 7 June 2019) for each country of Latin America, relative to the number of records that have been submitted by eBird users. The respective proportion is shown in the green scale.

\section{First open biodiversity database of Uruguay}

Here, we introduce Biodiversidata, the first database derived from the Uruguayan Consortium of Biodiversity Data (biodiversidata.org), a collaborative initiative aimed at hosting and distributing via an open-access platform a comprehensive database on the biodiversity of Uruguay. The total number of records collated is 69,380 , from across 673 species (Table 1). Biodiversidata contains primary biodiversity data (i.e. data records that 
document the occurrence of a species in space and time) from all the native amphibian, reptile, bird and mammal species recorded in Uruguay to date. Therefore, this paper is the first contribution in a series of phases aimed at improving the knowledge of the biodiversity of Uruguay and, importantly, establishing a fully open-access resource for the wider community from this point on. The data are currently being used to (i) identify spatial patterns of species richness, local endemism and endangerment within tetrapod species of Uruguay, to then assess the spatial congruence amongst these patterns, (ii) quantify the spatial and temporal incompleteness of the inventory and (iii) identify high priority areas of historically poor sampling ('hotspots of ignorance'), with the ultimate aim of facilitating the development of future sampling strategies and efforts to complete these gaps. This database, therefore, has been generated, based on the principle that collaboration amongst experts can strongly push forward the development of fields and, in this particular case, improve our knowledge on the biodiversity of Uruguay by overcoming data-scarcity and enriching the understanding of regional and larger-scale biodiversity patterns. Collectively, Biodiversidata offers the first open biodiversity repository for the country and the most comprehensive geographically and taxonomically resource for biodiversity and environmental studies in Uruguay to date.

Table 1.

Records collected per tetrapod class showing: number of occurrence records (non-duplicated records/location/year), total number of species, records without information of the date of collection and records collected in the last 30 years, with percentage in parentheses.

\begin{tabular}{|l|l|l|l|l|}
\hline & $\begin{array}{l}\text { Number of Occurrence } \\
\text { Records }\end{array}$ & $\begin{array}{l}\text { Number of } \\
\text { Species }\end{array}$ & $\begin{array}{l}\text { Records without Date } \\
\text { (\%) }\end{array}$ & $\begin{array}{l}\text { Records from the last 30 } \\
\text { years (\%) }\end{array}$ \\
\hline Amphibia & 2,530 & 51 & $1,780(70.4)$ & $683(27.0)$ \\
\hline Reptilia & 2,308 & 68 & $1,999(86.6)$ & $224(9.7)$ \\
\hline Aves & 60,627 & 437 & $131(0.2)$ & $60,308(99.5)$ \\
\hline Mammalia & 3,915 & 117 & $1,687(43.1)$ & $1,122(28.7)$ \\
\hline Total & 69,380 & 673 & & \\
\hline
\end{tabular}

\section{Sampling methods}

Sampling description: The database was developed, based on the collection of data from a range of different sources. A significant proportion of the data was collected by expert members of Biodiversidata. These records can be found with the value 'Unpublished data' under the term 'associatedReference'. A proportion of them has been deposited in national specimen collections such as the Mammalogy collection of the Museo Nacional de Historia Natural of Uruguay and the Vertebrate collection of the Facultad de Ciencias, Universidad de la República (Uruguay). In addition to the large volume of original data, we have also incorporated all readily available records from multiple sources, including online databases (i.e. GBIF) as well as data currently published but not available in the format of other sources of compiled information. These include data from primarily field guides and books 
and primary literature such as monographs, systematic accounts, species descriptions, reviews and reports of range extensions, in journals such as "Check List" and the local "Boletín de la Sociedad Zoológica del Uruguay", amongst others. A complete list of sources for the occurrence records is shown in Table 2. Most of the sources used are freely available online, while numerous other literature resources that document the primary biodiversity data of Uruguay still remain inaccessible.

Table 2.

List of sources used to build the dataset, including the source type and the number of records extracted from each of the sources.

\begin{tabular}{|c|c|c|c|}
\hline Source & Source type & $\begin{array}{l}\text { Number of } \\
\text { records }\end{array}$ & Groups \\
\hline Abreu (2015) & Journal Article & 8 & Aves \\
\hline Andrade-Núñez and Aide (2010) & Journal Article & 13 & Mammalia \\
\hline Azpiroz et al. (2012) & Journal Article & 54 & Aves \\
\hline Bardier and Maneyro (2015) & Journal Article & 20 & Amphibia \\
\hline Borteiro et al. (2006) & Journal Article & 70 & Reptilia \\
\hline Borteiro et al. (2009) & Journal Article & 1 & Reptilia \\
\hline Borteiro et al. (2013) & Journal Article & 4 & Reptilia \\
\hline Borteiro et al. (2015) & Journal Article & 13 & Reptilia \\
\hline Bou (2013) & Thesis & 86 & Mammalia \\
\hline Carreira and Achaval (2007) & Journal Article & 2 & Reptilia \\
\hline Carreira and Lombardo (2006) & Journal Article & 1 & Reptilia \\
\hline Carreira et al. (2005) & Book & 1880 & Reptilia \\
\hline Carreira et al. (2012) & Journal Article & 2 & Reptilia \\
\hline Colina et al. (2012) & Journal Article & 1 & Reptilia \\
\hline da Rosa & This study & 13 & Amphibia + Reptilia \\
\hline de Giorgi Peirano (2016) & Thesis & 67 & Aves \\
\hline Elgue and Maneyro (2017) & Journal Article & 1 & Amphibia \\
\hline GBIF.org & Online Database & 58355 & $\begin{array}{l}\text { Amphibia + Reptilia + Aves + } \\
\text { Mammalia }\end{array}$ \\
\hline Gobel \& Laufer & This study & 285 & Amphibia + Reptilia \\
\hline González-Paredes et al. (2017) & Journal Article & 3 & Reptilia \\
\hline González \& González & This study & 1848 & Mammalia \\
\hline
\end{tabular}




\begin{tabular}{|c|c|c|c|}
\hline Source & Source type & $\begin{array}{l}\text { Number of } \\
\text { records }\end{array}$ & Groups \\
\hline Grattarola & This study & 53 & Mammalia \\
\hline Grattarola (2015) & Thesis & 36 & Mammalia \\
\hline Hernández & This study & 944 & Aves \\
\hline Kolenc et al. (2009) & Journal Article & 2 & Amphibia \\
\hline Kolenc et al. (2012) & Journal Article & 2 & Amphibia \\
\hline Kwet et al. (2002) & Journal Article & 1 & Amphibia \\
\hline Lareschi et al. (2006) & Journal Article & 11 & Mammalia \\
\hline Laufer et al. (2009) & Journal Article & 2 & Amphibia \\
\hline Maneyro et al. (2008) & Journal Article & 2 & Amphibia \\
\hline Maneyro & This study & 165 & Amphibia + Reptilia \\
\hline Martínez-Lanfranco et al. (2010) & Journal Article & 6 & Mammalia \\
\hline Martínez-Lanfranco & This study & 1712 & Aves + Mammalia \\
\hline Masciadri et al. (2007) & $\begin{array}{l}\text { Conference } \\
\text { Paper }\end{array}$ & 48 & Amphibia + Reptilia + Aves \\
\hline Montero (2016) & Journal Article & 85 & Reptilia \\
\hline Naya and Achaval (2006) & Journal Article & 5 & Mammalia \\
\hline Naya & This study & 220 & Aves \\
\hline Núñez et al. (2004) & Book & 1764 & Amphibia \\
\hline Prigioni et al. (2011) & Journal Article & 43 & Amphibia + Reptilia \\
\hline Prigioni et al. (2013) & Journal Article & 18 & Reptilia \\
\hline Prigioni et al. (2018) & Journal Article & 3 & Mammalia \\
\hline Queirolo (2016) & Journal Article & 1041 & Mammalia \\
\hline Rodales, Botto \& González & This study & 91 & Mammalia \\
\hline Rodríguez-Cajarville et al. (2017) & Journal Article & 4 & Aves \\
\hline Rodríguez-Mazzini et al. 2001 & Report & 151 & Amphibia + Reptilia + Mammalia \\
\hline Santana et al. (2013) & Journal Article & 1 & Amphibia \\
\hline Sarroca et al. 2009 & Report & 189 & $\begin{array}{l}\text { Amphibia + Reptilia + Aves + } \\
\text { Mammalia }\end{array}$ \\
\hline $\begin{array}{l}\text { Vaz-Canosa and Rodríguez-Cajarville } \\
\text { (2015) }\end{array}$ & Journal Article & 1 & Aves \\
\hline
\end{tabular}




\begin{tabular}{|l|l|l|l|}
\hline Source & Source type & $\begin{array}{l}\text { Number of } \\
\text { records }\end{array}$ & Groups \\
\hline Velasco-Charpentier et al. (2016) & Journal Article & 4 & Reptilia \\
\hline Verrastro et al. (2006) & Journal Article & 3 & Reptilia \\
\hline Verrastro et al. (2017) & Journal Article & 1 & Reptilia \\
\hline Villamil (2014) & Journal Article & 15 & Reptilia \\
\hline Ziegler & This study & 31 & Amphibia \\
\hline
\end{tabular}

The GBIF dataset was obtained by searching for Uruguay in the 'country or area' field (as for 15 January 2018), retrieving 185,519 occurrences from 573 datasets, including 8,925 species of Animalia, Plantae, Fungi, Bacteria, Chromista, Protozoa and Archaea. These data on species occurrences are available on the GBIF portal at https://doi.org/10.15468/ dl.dmul8x. Most of these records were submitted by the eBird project (56.1\% of the total amount) and the rest derive from diverse specimen collections around the world, such as the National Museum of Natural History Smithsonian Institution (4.2\%), the Instituto de Botánica Darwinion in Argentina (3.9\%), the Missouri Botanical Garden's Herbarium (3\%), the Museo Argentino de Ciencias Naturales "Bernardino Rivadavia" (2.1\%), the Swedish Museum of Natural History (1.6\%), the Museum of Comparative Zoology at Harvard University (0.72\%), the American Museum of Natural History of New York (0.68\%) and the Natural History Museum of London (0.57\%). None of the records was submitted by Uruguayan institutions, most likely because of the major public sources of specimen biodiversity information (government and academia) are not open nor publicly available.

Quality control: Different methods were applied to treat the data derived from each of the above-mentioned sources. For the GBIF data, only records of amphibians, reptiles, birds and mammals were included in this first version. Exotic species and records without complete date of collection/observation or geographic location information were excluded. The data from literature were manually extracted and added to the data collected by members of Biodiversidata. These records were controlled by collection and catalogue number to check their complete independence from the GBIF data. To avoid pseudoreplication in posterior analyses, records were filtered by considering only one record per locality/year. If more than one organism of the same species was collected in a locality in the same year (i.e. same geographic coordinates), we kept the first and most complete record (i.e. the most informative record for the year).

In line with FAIR data Principles (Wilkinson et al. 2016), the database was prepared to improve the findability, accessibility, interoperability and reuse of the data collated. We manually adapted the data following the Darwin Core Biodiversity Data Standard (DwC) (Wieczorek et al. 2012), incorporating 32 descriptive terms (see Data resources section for a full description of each column heading). Likewise, we created a persistent and global identifier for each record, included well-described metadata and applied the most accessible usage licence to the data. 
A significant number of the data lacked crucial information in terms of taxon, time and place of collection/observation, a common issue with observational and specimen data (Peterson et al. 2018). Thus, the treating of the vastly heterogeneous records included updating scientific names inconsistencies and the georeferencing of sampling locations when sufficient information was provided. For standardisation of species names and complete taxonomic categories retrieval, we used the R package 'taxize' (Chamberlain et al. 2018). We followed the Integrated Taxonomic Information System database (itis.gov) and the specific reference according to the taxonomic group: Amphibian Species of the World of the American Museum of Natural History, BirdLife International, The Mammal Species of The World and The Reptile Database. For conservation status retrieval according to the IUCN Red List, we used the R package 'rredlist' (Chamberlain 2018). The R scripts used can be found at Grattarola (2019). Georeferenced point data resulted from either GPS measurements, direct estimates of the latitude and longitude of an observation when route and kilometre number data were available or by defining the latitude and longitude of the event locality through the GeoNames Gazetteer database (geonames.org). The details of how geographic latitude and longitude were obtained can be found under the term 'georeferenceSources'.

\section{Geographic coverage}

Description: The database includes all native and extant species of tetrapods reported in any area within the borders of Uruguay. The occurrence records are not evenly distributed through space as a result of oversampling in some areas and of limited (or no) sampling in other areas (Fig. 2a). When we consider the records of the last 30 years, the geographic coverage amongst groups reduces enormously and becomes dominated by birds (Fig. 2b).

Higher numbers of records are seen in the coast area, whilst the centre of the country holds low sampling densities. The most sampled area of Uruguay is in Montevideo (the capital of the country), followed by the surroundings of Maldonado and Rocha cities, all Atlantic coast areas. We observed this pattern particularly in Aves which, despite being the most sampled group, with $87.4 \%$ of the database records, they are strongly spatially biased. Reptiles, on the other hand, with the least number of records in the database, cover the Uruguayan territory better than any other tetrapod group.

After our data collation, we can observe some areas of the country that remain systematically ignored. This disparity in sampling is mostly due to the lack of systematisation in the efforts of zoological exploration of the national territory and responds to the realisation of research projects, faunistic inventories or intensive occasional sampling in a few locations, generally near the main population centres or close to easily accessible areas (Carreira et al. 2005, Soutullo et al. 2013). As can be seen in Fig. 2, areas with more sampling effort tend to be located adjacent to national routes. Nevertheless, this is the first country-wide effort aimed at tackling biodiversity data being lost. In the future, there is substantial work to be done on digitisation and tactical direction of new sampling efforts to enhance the territorial coverage to develop a more accurate 
picture of the distribution of biodiversity in the country. Therefore, a critical first contribution of the Uruguayan Consortium of Biodiversity Data will involve establishing areas where efforts are urgently needed at the expense of areas that have been historically oversampled.

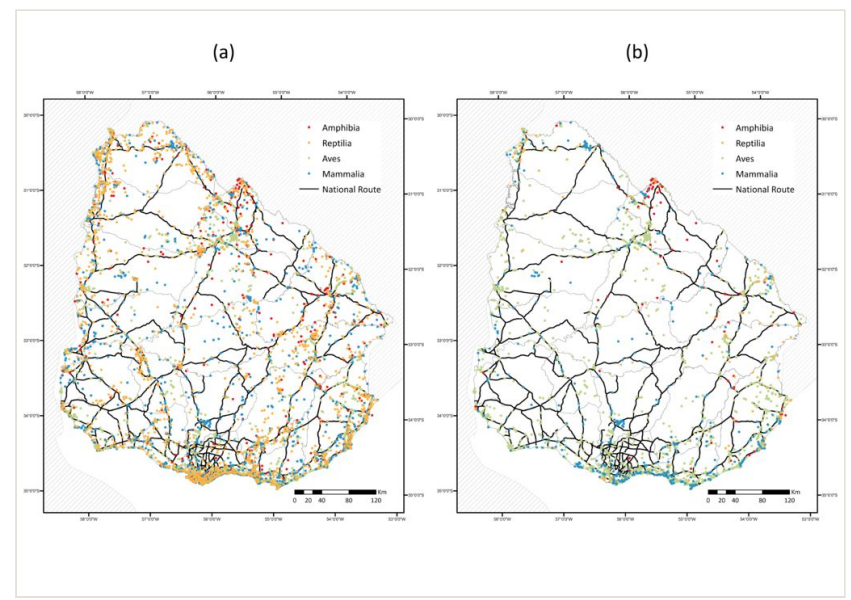

Figure 2. doi

Distribution of the (a) total number of occurrence records $(N=69,380)$ from species of amphibians, reptiles, birds and mammals from Uruguay and (b) occurrence records from the last 30 years. National routes are shown in black. Projection WGS1984 UTM zone 21S.

Coordinates: -34.973188 and -30.10818 Latitude; -58.43882 and -53.266525 Longitude.

\section{Taxonomic coverage}

Description: The database incudes 69,380, representing 129 families, 446 genera and 673 species: 51 amphibians, 68 reptiles, 437 birds and 117 mammals. The taxonomic coverage is uneven (Fig. 3). For instance, ten bird species make up to $14 \%$ of the database records, while $10 \%$ of the tetrapod species have only been observed/collected once. Likewise, occurrence records within groups are dominated by their most sampled species, such as Boana pulchella $(\mathrm{N}=248)$ and Pseudis minuta $(\mathrm{N}=195)$ in Amphibia, Philodryas patagoniensis $(\mathrm{N}=176)$ and Erythrolamprus poecilogyrus $(\mathrm{N}=139)$ in Reptilia, Pitangus sulphuratus $(\mathrm{N}=1191)$ and Furnarius rufus $(\mathrm{N}=1180)$ in Aves and Akodon azarae $(\mathrm{N}=207)$ and Scapteromys tumidus $(\mathrm{N}=187)$ in Mammalia.

Taxa included:

\begin{tabular}{|l|l|l|}
\hline Rank & Scientific Name & Common Name \\
\hline kingdom & Animalia & Animals \\
\hline subkingdom & Eumetazoa & \\
\hline
\end{tabular}




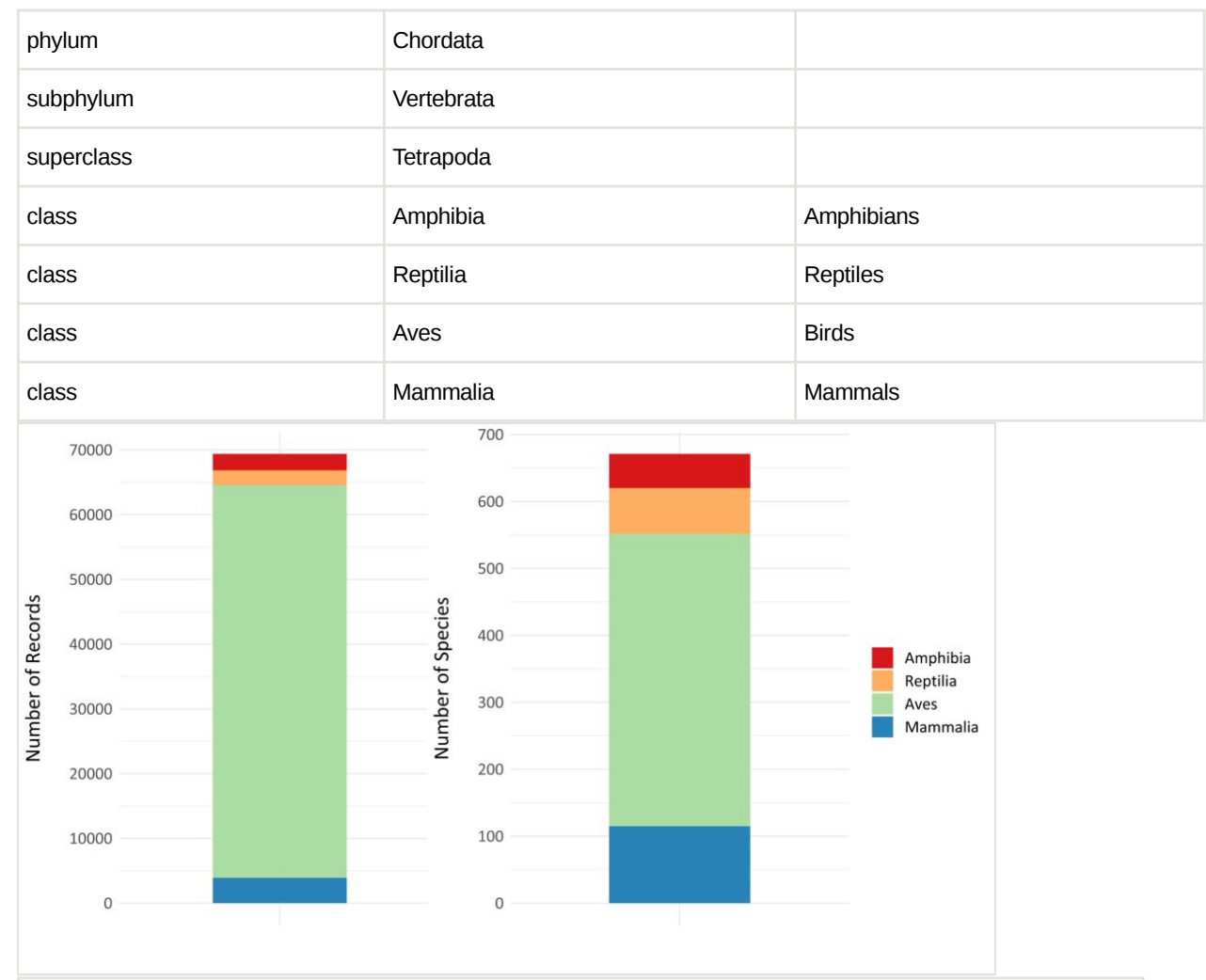

Figure 3. doi

Distribution of the number of occurrence records and number of species collated for each class of the tetrapod group.

\section{Temporal coverage}

Notes: The records included in Biodiversidata cover samples reported in Uruguay during the period of 1806-2018 (Fig. 4). We observed that occurrence records have been collected mostly intermittently within groups, with a continuously increasing tendency since the beginning of the 20th Century. The steady increase towards the latter half of the century is in part a result of the creation of the School of Science (1945) and several field work expeditions during the next decades that resulted in an increase in the production of research articles (Soutullo et al. 2013). In the case of the records collected from literature, there was a high number lacking date of collection or observation. For instance, a large number of the records collated from Carreira et al. (2005), a detailed scientific monograph on the reptiles of Uruguay, provides location but no date associated to the records. We aim to promote the need to associate spatial records to dates of collection of the datapoints, as this approach is expected to facilitate the development of scientific-based decisions when implementing environmental policies (Peterson et al. 2018). Overall, as was mentioned 
above, numerous other literature sources and specimens recorded in the country yet need to become digitally accessible, hence, Uruguay will face a great challenge in "rescuing" these data in the future to prevent them being lost.

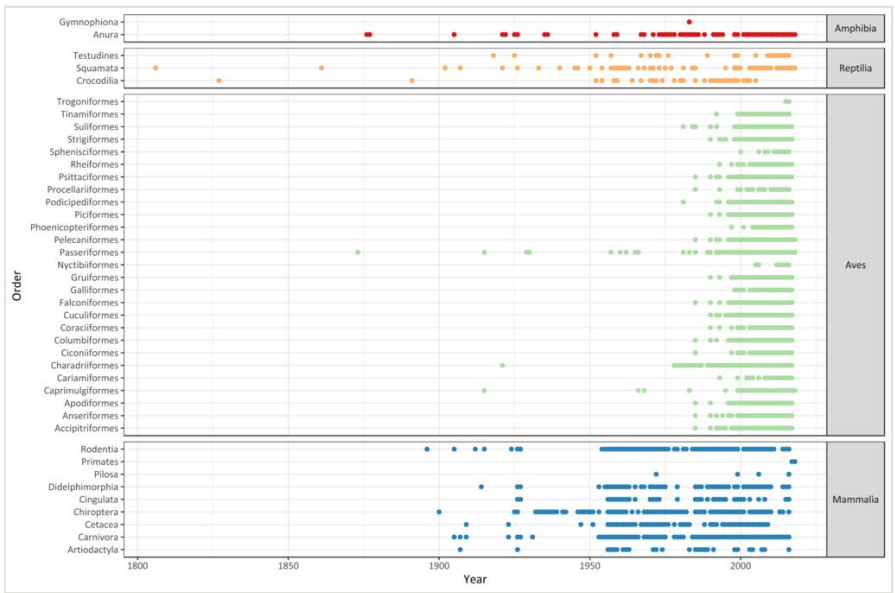

Figure 4. doi

Occurrence records of tetrapod orders reported in Uruguay over time, divided by amphibians, reptiles, birds and mammals.

In particular, bird occurrence records are disproportionally superior in the database (i.e. $87.4 \%$ of total number of records), presenting an intense period of sampling effort between 2000 and 2016, mostly derived from citizen science efforts from eBird users (collected from GBIF). Regardless of the spatial bias of these records, it is valuable to note the significant contribution of local ornithologists and birdwatchers (i.e. Aves Uruguay) to the international initiative, which probably stands as the richest and oldest practice of data-sharing known in Uruguay.

\section{Usage rights}

Use license: Creative Commons Public Domain Waiver (CC-Zero)

\section{Data resources}

Data package title: Biodiversidata

\section{Number of data sets: 1}

Data set name: Biodiversidata: An Open-Access Database for the Biodiversity of Uruguay: 1806-2018

Character set: UTF-8 
Download URL: doi.org/10.5281/zenodo.2650169

\section{Data format: Darwin Core Archive}

Data format version: 1.0

Description: The dataset provides primary biodiversity data on extant Amphibia, Reptilia, Aves and Mammalia species recorded within the country area between 1806-2018. The total number of records collated is 69,380 , including 673 species. Suppl. material 1

\begin{tabular}{|c|c|}
\hline Column label & Column description \\
\hline occurrencelD & $\begin{array}{l}\text { An identifier for the Occurrence (as opposed to a particular digital record of the occurrence), } \\
\text { constructed from a combination of identifiers in the record that will most closely make the } \\
\text { occurrencelD globally unique. }\end{array}$ \\
\hline scientificName & The full scientific name, with authorship and date information \\
\hline scientificNameAuthorship & The authorship information for the scientificName \\
\hline vernacularName & Common or vernacular name in Uruguay (in Spanish) \\
\hline kingdom & The full scientific name of the kingdom in which the taxon is classified \\
\hline phylum & The full scientific name of the phylum or division in which the taxon is classified \\
\hline class & The full scientific name of the class in which the taxon is classified \\
\hline order & The full scientific name of the order in which the taxon is classified \\
\hline family & The full scientific name of the family in which the taxon is classified \\
\hline genus & The full scientific name of the genus in which the taxon is classified \\
\hline specificEpithet & The name of the first or species epithet of the scientificName \\
\hline infraspecificEpithet & $\begin{array}{l}\text { The name of the lowest or terminal infraspecific epithet of the scientificName, excluding any } \\
\text { rank designation }\end{array}$ \\
\hline countryCode & The standard code for the country in which the Location occurs \\
\hline stateProvince & $\begin{array}{l}\text { The name of the next smaller administrative region than country (department) in which the } \\
\text { Location occurs }\end{array}$ \\
\hline verbatimLocality & The original textual description of the place \\
\hline decimalLatitude & The geographic latitude (in decimal degrees) \\
\hline decimalLongitude & The geographic longitude (in decimal degrees) \\
\hline georeferenceSources & A list of maps, gazetteers or other resources used to georeference the Location \\
\hline georeferencedBy & $\begin{array}{l}\text { A person, group or organisation who determined the georeference (spatial representation) } \\
\text { for the Location. }\end{array}$ \\
\hline eventDate & The date when the event was recorded. Format: dd-mm-yyyy \\
\hline
\end{tabular}




\begin{tabular}{|c|c|}
\hline year & The four-digit year in which the Event occurred. Format: yyyy \\
\hline month & The ordinal month in which the Event occurred. Format: $\mathrm{mm}$ \\
\hline day & The integer day of the month on which the Event occurred. Format: dd \\
\hline basisOfRecord & The specific nature of the data record \\
\hline institutionCode & $\begin{array}{l}\text { The name (or acronym) in use by the institution having custody of the object(s) or } \\
\text { information referred to in the record }\end{array}$ \\
\hline collectionCode & The name or acronym identifying the collection or dataset from which the record was derived \\
\hline catalogNumber & An identifier (preferably unique) for the record within the dataset or collection \\
\hline recordedBy & $\begin{array}{l}\text { A list (concatenated and separated) of names of people, groups or organisations responsible } \\
\text { for recording the original Occurrence }\end{array}$ \\
\hline recordNumber & $\begin{array}{l}\text { An identifier given to the Occurrence at the time it was recorded. Often serves as a link } \\
\text { between field notes and an Occurrence record, such as a specimen collector's number. }\end{array}$ \\
\hline identifiedBy & $\begin{array}{l}\text { A list (concatenated and separated) of names of people, groups or organisations who } \\
\text { assigned the Taxon to the subject }\end{array}$ \\
\hline dynamicProperties & $\begin{array}{l}\text { Structured content about the record key:value encoding IUCN red list category of the taxon } \\
\text { at the Global level }\end{array}$ \\
\hline associatedReferences & $\begin{array}{l}\text { A list (concatenated and separated) of identifiers (publication, bibliographic reference, global } \\
\text { unique identifier, URI) of literature associated with the Occurrence }\end{array}$ \\
\hline
\end{tabular}

\section{Additional information}

The Uruguayan Consortium of Biodiversity Data, is a collaborative association of experts whose aim is to improve Uruguay's biodiversity knowledge. It was created in 2018 by Florencia Grattarola as part of her PhD project. Its open-access platform (biodiversidata.or g) aims to make available the biodiversity data of Uruguay by integrating a broad range of resources including databases, publications, maps, reports and infographics, derived from the work of the team members. The database presented in this study and the original research that is currently emerging from it are the first products of the initiative and will be available in the platform. The database may continue to be updated with new records periodically; check the Zenodo repository for the latest version: https://doi.org/10.5281/ zenodo.2650169.

\section{Acknowledgements}

The research leading to these results has received funding from Agencia Nacional de Investigación e Innovación (ANII POS_EXT_2016_1_136663). Laufer G., Maneyro R., Naya D. E. and Ziegler L. wish to thank the National System of Researchers (Sistema Nacional de Investigadores, SNI-ANII, Uruguay). 


\section{Author contributions}

F.G. was responsible for data compilation, standardisation, quality control and management. F.G. and D.P.D. have drafted the first manuscript. G.B., I.D.R., N.G., E.M.G., J.G., F.G., D.H., G.L., R.M., J.A.M.L., D.E.N., A.L.R. and L.Z. contributed with acquisition of data. All authors collaboratively contributed to analysis and interpretation of the data and finalised the manuscript.

We declare that the joint co-authorship of this article, or the affiliation to the Biodiversidata initiative, does not imply responsibility of any individual, directly or indirectly, for the principles and values of other members or co-authors.

\section{References}

- $\quad$ Abreu M (2015) Primer registro de la gaviota de Franklin Leucophaeus pipixcan (Wagler, 1831) (Aves: Laridae) en Uruguay. Boletín de la Sociedad Zoológica del Uruguay $24:$

22-27. URL: http://szu.org.uy/boletin/vol24_1/22_27 vol24_1.pdf

- $\quad$ Andrade-Núñez MJ, Aide TM (2010) Effects of habitat and landscape characteristics on medium and large mammal species richness and composition in northern Uruguay. Zoologia 27 (6). https://doi.org/10.1590/S1984-46702010000600012

- $\quad$ Arballo E, Cravino J (1999) Aves del Uruguay: Manual Ornitologico. 1. Editorial Hemisferio Sur, 466 pp. [ISBN 9974-645-08-5]

- $\quad$ Azpiroz AB, Menéndez JL, Jaramillo A, Presa D, Calimares C, Saralegui A, Abente JS (2012) New information on the distribution and status of birds in Uruguay. Bulletin of the British Ornithologists' Club 132 (1): 46-54. URL: http://biostor.org/reference/246835

- $\quad$ Bardier C, Maneyro R (2015) Inventory and conservation priorities for amphibian species from Cerro Verde (Rocha, Uruguay) and surroundings. Check List 11 (2): 1-8. https:// doi.org/10.15560/11.2.1581

- $\quad$ Borteiro C, Prigioni C, García JE, Tedros M, Gutiérrez F, Kolenc F (2006) Geographic distribution and conservation status of Caiman latirostris (Crocodylia, Alligatoridae) in Uruguay. Journal of Herpetology 5 (2): 97-108. https://doi.org/10.11606/ issn.2316-9079.v5i2p97-108

- $\quad$ Borteiro C, Gutiérrez F, Tedros M, Kolenc F (2009) Food habits of the broad-snouted caiman (Caiman latirostris: Crocodylia, Alligatoridae) in northwestern Uruguay. Studies on Neotropical Fauna and Environment 44 (1): 31-36. https://

doi.org/10.1080/01650520802507572

- $\quad$ Borteiro C, Kolenc F, Verdes JM (2013) Aggregative behaviour in the fossorial lizard Amphisbaena darwinii (Squamata, Amphisbaenidae). Cuadernos de herpetología 27 (1): 57-58. URL: http://sedici.unlp.edu.ar/handle/10915/26859

- $\quad$ Borteiro C, Kolenc F, Prigioni C (2015) A new noteworthy record of Phrynops williamsi Rhodin \& Mittermeier (Testudines, Chelidae) in Uruguay. Cuadernos de herpetología 29 (1): 95-96. URL: http://sedici.unlp.edu.ar/handle/10915/56007

- Bou N (2013) Distribución potencial de tres especies de Leopardus (Carnivora: Felidae) para Uruguay. Universidad de la República (Uruguay) URL: https:// www.colibri.udelar.edu.uy/jspui/bitstream/20.500.12008/6419/1/uy24-16158.pdf 
- $\quad$ Calliari D, Defeo O, Cervetto G, Gómez M, Giménez L, Scarabino F, Brazeiro A, Norbis W (2003) Marine Life of Uruguay: Critical Update and Priorities for Future Research. Gayana (Concepción) 67: 341-370. https://doi.org/10.4067/S0717-65382003000200015

- Canavero A, Brazeiro A, Camargo A, da Rosa I, Maneyro R, Núñez D (2010) Amphibian diversity of Uruguay: Background knowledge, inventory completeness and sampling coverage. Boletín de la Sociedad Zoológica de Uruguay 19: 2-19. URL: http:// www.szu.org.uy/boletin/vol19/1_19 vol19.pdf

- $\quad$ Carreira S, Meneghel M, Achaval F (2005) Reptiles de Uruguay. Sección Zoología Vertebrados, Departamento de Biología Animal, Facultad de Ciencias [ISBN 9974002842]

- Carreira S, Lombardo I (2006) Tomodon dorsatus (NCN). Uruguay. Herpetological Review 37 (1): 110. URL: https://ssarherps.org/herpetological-review-pdfs

- $\quad$ Carreira S, Achaval F (2007) Sobre la presencia de Waglerophis merremi (Wagner, 1824) en Uruguay (Reptilia: Squamata). Boletín de la Sociedad Zoológica de Uruguay 16: 32-35. URL: http://www.szu.org.uy/boletin/vol16/32_35 vol16.pdf

- $\quad$ Carreira S, Lombardo I, Achaval-Coppes F (2012) Nuevos registros de ofidios poco conocidos en Uruguay (Reptilia: Squamata: Serpentes). Boletín de la Sociedad Zoológica del Uruguay (2a época) 21: 70-74. URL: http://www.szu.org.uy/boletin/

vol21/70 74_vol21.pdf

- $\quad$ Chamberlain S (2018) rredlist: 'IUCN' Red List Client. R package. 0.5.0.. URL: https:// CRAN.R-project.org/package=rredlist

- $\quad$ Chamberlain S, Szoecs E, Foster Z, Arendsee Z, Boettiger C, Ram K, Bartomeus I, Baumgartner J, O'Donnell J, Oksanen J, Greshake Tzovaras B, Marchand P, Tran V (2018) taxize: Taxonomic information from around the web. R package. 0.9.3. URL: https:// github.com/ropensci/taxize

- Chebataroff J (1942) La vegetación del Uruguay y sus relaciones fitogeográficas con la del resto de la América del Sur. Revista Geográfica 2 (4/5/6): 49-90. URL: https:// www.jstor.org/stable/41888194

- $\quad$ Colina M, Arrieta D, Carreira S (2012) Ophiodes intermedius Boulenger, 1894 (Squamata: Anguidae): Uruguay distribution extension with conservation comments. Check List 8 (5): 896-897. https://doi.org/10.15560/8.5.896

- de Giorgi Peirano A (2016) Diversidad de aves y mamíferos presentes en tres campos de soja en el departamento de Colonia y su relación con el daño a dicho cultivo. Universidad de la República URL: https://www.colibri.udelar.edu.uy/jspui/

bitstream/20.500.12008/8872/1/uy24-18205.pdf

- Dos Santos DA, Emmerich D, Molineri C, Nieto C, Domínguez E (2016) On the position of Uruguay in the South American biogeographical puzzle: insights from Ephemeroptera (Insecta). Journal of Biogeography 43 (2): 361-371. https://doi.org/10.1111/jbi.12623

- Elgue E, Maneyro R (2017) Reproductive biology in a Uruguayan population of Elachistocleis bicolor (Guérin-Meneville, 1838)(Anura, Microhylidae). Cuadernos de herpetología 31 (1): 5-10. URL: http://sedici.unlp.edu.ar/handle/10915/60099

- Gonzalez EM, Martínez-Lanfranco JA (2010) Zoogeografía de los mamíferos de Uruguay. Mamíferos de Uruguay. Guía de campo e introducción a su estudio y conservación. Banda Oriental, MNHN y Vida Silvestre Uruguay, 6 pp. [ISBN 978 9974-1-0674-1].

- González-Paredes D, Vélez-Rubio G, Hahn AT, Caraccio MN, Estrades A (2017) New records of Lepidochelys olivacea (Eschscholtz, 1829) (Testudines, Cheloniidae) provide evidence that Uruguayan waters are the southernmost limit of distribution for the species in the western Atlantic Ocean. Check List 13 (6): 863-869. https://doi.org/10.15560/13.6.863 
- Grattarola F (2015) Aportes de la ecología molecular al estudio de mamíferos en Uruguay. Universidad de la República, Montevideo, Uruguay. URL: https://www.colibri.udelar.edu.uy/ jspui/bitstream/20.500.12008/17162/1/uy24-17527.pdf

- $\quad$ Grattarola F (2019) rBiodiversidata: R scripts. 1.0.0. Zenodo. Release date: 2019-4-16. URL: https://doi.org/10.5281/zenodo.2642135

- Grela I, Brussa C (2003) Relevamiento florístico y análisis comparativo de comunidades arbóreas de Sierra de Ríos (Cerro Largo-Uruguay). Agrociencia 7 (2): 11-26. URL: http:// www.fagro.edu.uy/ agrociencia/index.php/directorio/article/view/364

- Grela I (2004) Geografía florística de las especies arbóreas de Uruguay: propuesta para la delimitación de dendrofloras. PEDECIBA - Universidad de la República, Montevideo.

- $\quad$ Kolenc F, Borteiro C, Baldo D, Ferraro D, Prigioni C (2009) The tadpoles and advertisement calls of Pleurodema bibroni Tschudi and Pleurodema kriegi (Müller), with notes on their geographic distribution and conservation status (Amphibia, Anura, Leiuperidae). Zootaxa 1969: 1-35. https://doi.org/10.5281/zenodo.185006

- Kolenc F, Borteiro C, González EM, Barrasso DA, Prigioni C (2012) Recent findings of the declining frog Pleurodema bibroni Tschudi, 1838 (Anura: Leiuperidae) in Uruguay. Herpetology Notes 5: 181-183. URL: http://www.herpetologynotes.seh-herpetology.org/ Volume5_PDFs/Kolenc Herpetology Notes Volume5_pages181-183.pdf

- $\quad$ Kwet A, Solé M, Miranda T, Melchiors J, Naya D, Maneyro R (2002) First record of Hyla albopunctata Spix, 1824 (Anura: Hylidae) in Uruguay, with comments on the advertisement call. Boletín de la Asociación Herpetológica Española 13: 15-19.

- Lareschi M, Venzal JM, Arzua M, González E (2006) Fleas of small mammals in Uruguay, with new host and distribution records. Comparative Parasitology 73 (2): 263-269. https:// doi.org/10.1654/4193.1

- $\quad$ Laufer G, Piñeiro-Guerra JM, Pereira-Garbero R, Barreneche JM, Ferrero R (2009) Distribution extension of Scinax aromothyella (Anura, Hylidae). Biota Neotropica 9 (2): 275-277. https://doi.org/10.1590/S1676-06032009000200028

- Maneyro R, Naya DE, Baldo D (2008) A new species of Melanophryniscus (Anura, Bufonidae) from Uruguay. Iheringia. Série Zoologia 98 (2): 189-192. https:// doi.org/10.1590/S0073-47212008000200003

- Martínez-Lanfranco JA, Rudolf JC, Queirolo D (2010) Puma concolor (Carnivora, Felidae) en Uruguay: situación local y contexto regional. Mastozoología Neotropical 17 (1): 153-159. URL: http://www.redalyc.org/articulo.oa?id=45713277018

- $\quad$ Masciadri S, Da Rosa I, Alfaro M (2007) Diversidad biológica del Bosque Costero en la localidad Perla de Rocha. IV Congreso Nacional de Áreas Naturales Protegidas, Trinidad, Florida.

- $\quad$ Montero R (2016) On the validity of several Argentinian species of Amphisbaena (Squamata, Amphisbaenidae). Journal of Herpetology 50 (4): 642-653. https:// doi.org/10.1670/15-048

- Morrone JJ (2006) Biogeographic areas and transition zones of Latin America and the Caribbean islands based on panbiogeographic and cladistic analyses of the entomofauna. Annu. Rev. Entomol. 51: 467-494. https://doi.org/10.1146/annurev.ento.50.071803.130447

- Morrone JJ (2014) Biogeographical regionalisation of the Neotropical region. Zootaxa 3782 (1): 1-110. https://doi.org/10.11646/zootaxa.3782.1.1

- $\quad$ Naya DE, Achaval F (2006) Nuevos registros de especies poco comunes de Pinnipedia y primer registro de Arctocephalus gazella (Peters, 1875) (Pinnipedia: Otariidae) para el 
Uruguay. Boletín de la Sociedad Zoológica de Uruguay 15: 23-27. URL: http:// www.szu.org.uy/boletin/vol15/23 27 vol15.pdf

- Núñez D, Maneyro R, Langone J, de Sa RO (2004) Distribución geográfica de la fauna de anfibios del Uruguay. Smithsonian Herpetological Information Service 1-34. https:// doi.org/10.5479/si.23317515.134.1

- Peterson AT, Asase A, Canhos DAL, de Souza S, Wieczorek J (2018) Data Leakage and Loss in Biodiversity Informatics. Biodiversity Data Journal 6 https://doi.org/10.3897/ BDJ.6.e26826

- $\quad$ Pincheira-Donoso D (2010) The untold story on the ecological and phylogenetic complexity of the Uruguayan reptile fauna. Zootaxa 2354 (1): 67-68. https://doi.org/10.11646/ zootaxa.2354.1.6

- $\quad$ Prigioni C, Borteiro C, Kolenc F (2011) Amphibia and Reptilia, Quebrada de los Cuervos, Departamento de Treinta y Tres, Uruguay. Check List 7 (6): 763-767. https:// doi.org/10.15560/11021

- $\quad$ Prigioni C, Borteiro C, Kolenc F, Colina M, González EM (2013) Geographic distribution and apparent decline of Crotalus durissus terrificus (Laurenti, 1768; Serpentes, Viperidae) in Uruguay. Cuadernos de Herpetología 27 (2): 163-1625. URL: http://sedici.unlp.edu.ar/ handle/10915/38558

- $\quad$ Prigioni C, Villalba J, Sappa A, González J (2018) Confirmación de la presencia del mono aullador negro (Alouatta caraya) (Mammalia, Primates, Atelidae) en el Uruguay. Acta Zoológica Platense 1 (10): 1-11. URL: http://actazoologicaplatense.blogspot.com/2018/09/ acta-zoologica-platense-alouatta 17.html

- Queirolo D (2016) Diversidade e padrões de distribuição de mamíferos dos campos do Uruguai e sul do Brasil. Boletín de la Sociedad Zoológica del Uruguay 25 (2): 92-247. URL: http://szu.org.uy/journal/index.php/Bol SZU/article/view/11

- Rodríguez-Cajarville MJ, Arballo E, Gambarotta JC (2017) First documented records of Eastern Kingbird, Tyrannus tyrannus Linnaeus, 1758 (Aves: Tyrannidae) Uruguay. Check List 13 (4): 169-172. https://doi.org/10.15560/13.4.169

- Rodríguez-Mazzini R, Azpiroz AB, Báez F, Bonifacino M, Molina B, Prigioni C (2001) Evaluaciones ecológicas rápidas aplicadas a la Reserva de Biosfera Bañados del Este. Technical Report. PROBIDES: Documento de Trabajo N36 URL: http:// www.probides.org.uy/publica/dt/DT36.pdf

- Santana DJ, de Souza Queiroz S, Wanderley PS, de Avelar São-Pedro V, Leite FSF, Garda AA (2013) Calls and tadpoles of the species of Lysapsus (Anura, Hylidae, Pseudae). Amphibia-Reptilia 34 (2): 201-215. https://doi.org/10.1163/15685381-00002885

- Sarroca M, Rodríguez-Gallego L, Conde D (2009) La Laguna de las Nutrias: un ecosistema único en la costa de Uruguay. Technical Report. Informe técnico de la Sección Limnología, Facultad de Ciencias.

- $\quad$ Soutullo A, Clavijo C, Martínez-Lanfranco J (Eds) (2013) Especies prioritarias para la conservación en Uruguay. Vertebrados, moluscos continentales y plantas vasculares. SNAP/DINAMA/MVOTMA \& DICYT/MEC, Montevideo, 222 pp. [ISBN 978-9974-8259-7-0]

- Vaz-Canosa P, Rodríguez-Cajarville MJ (2015) Primer registro de Buteo brachyurus (Aves: Accipitriformes: Accipitridae) para Uruguay. Boletín de la Sociedad Zoológica del Uruguay 24 (1): 28-32. URL: http://szu.org.uy/boletin/vol24_1/28_32_vol24_1.pdf

- Velasco-Charpentier C, Pizarro-Mora F, Estrades A, Veléz-Rubio GM (2016) Epibiontes en juveniles de tortugas carey Eretmochelys imbricata varadas en la costa del Departamento 
de Rocha, Uruguay. Revista de biología marina y oceanografía 51 (2): 449-453. https:// doi.org/10.4067/S0718-19572016000200022

- $\quad$ Verrastro L, Schossler M, Silva C (2006) Liolaemus occipitalis. Herpetological Review 37 (4). URL: https://ssarherps.org/herpetological-review-pdfs/

- Verrastro L, Maneyro R, Da Silva CM, Farias I (2017) A new species of lizard of the $L$. wiegmannii group (Iguania: Liolaemidae) from the Uruguayan Savanna. Zootaxa 4294 (4): 443-461. https://doi.org/10.11646/zootaxa.4294.4.4

- Villamil J (2014) Lista sistemática de la fauna de reptiles de La Colorada Montevideo, Uruguay. Boletín de la Sociedad Zoológica de Uruguay (2ª́poca) 23 (2): 85-95. URL: http://szu.org.uy/boletin/vol23 2/85 95 vol23 2.pdf

- Wieczorek J, Bloom D, Guralnick R, Blum S, Döring M, Giovanni R, Robertson T, Vieglais D (2012) Darwin Core: An evolving community-developed biodiversity data standard. PLoS One 7 (1): e29715. https://doi.org/10.1371/journal.pone.0029715

- Wilkinson M, Dumontier M, Aalbersberg IJ, Appleton G, Axton M, Baak A, Blomberg N, Boiten J, da Silva Santos LB, Bourne P, Bouwman J, Brookes A, Clark T, Crosas M, Dillo I, Dumon O, Edmunds S, Evelo C, Finkers R, Gonzalez-Beltran A, Gray AG, Groth P, Goble C, Grethe J, Heringa J, 't Hoen PC, Hooft R, Kuhn T, Kok R, Kok J, Lusher S, Martone M, Mons A, Packer A, Persson B, Rocca-Serra P, Roos M, van Schaik R, Sansone S, Schultes E, Sengstag T, Slater T, Strawn G, Swertz M, Thompson M, van der Lei J, van Mulligen E, Velterop J, Waagmeester A, Wittenburg P, Wolstencroft K, Zhao J, Mons B (2016) The FAIR Guiding Principles for scientific data management and stewardship. Scientific Data 3 https://doi.org/10.1038/sdata.2016.18

\section{Supplementary material}

\section{Suppl. material 1: Data for tetrapods occurrence records of Uruguay_ doi}

Authors: Florencia Grattarola

Data type: Primary biodiversity data

Brief description: Tab-delimited csv data file and $\mathrm{xml}$ metadata file corresponding to the 69,380 species occurrence records held in the database

Download file (2.00 MB) 